\title{
Economic and Energy Performance of Brazilian Bagasse-Derived Ethanol: A Macro Perspective
}

Silvia Palma-Rojas ${ }^{1}$, Armando Caldeira-Pires ${ }^{1}$ and Jorge Nogueira ${ }^{2}$

${ }^{1}$ Department of Mechanical Engineering, Faculty of Technology, University of Brasilia, Brazil

${ }^{2}$ Institute of Economy, University of Brasilia, Brazil

\begin{abstract}
The increase of global biofuel production is supported mainly by energetic policies adopted by important energy markets that aim to promote the production and use of biofuels, including the promising cellulosic-derived biofuels. Brazil is facing a challenge to attain sustainability in ethanol sector and to maintain its position as a major supplier of ethanol to world market in this new era of sustainable biofuel policies. In this paper we carried out a structural path analysis on sugarcane-derived ethanol sector and on a hypothetical bagasse-derived ethanol sector in order to identify the input paths that most influencing their economic and environmental performance. We make an empirical application to the Brazilian economy, using existing data from ethanol sector for 2005 and estimating data for the hypothetical sector. The fuel burned in the transport sector and on-site transport tasks is identified as important element for the environmental performance of both sectors. Also, sugarcane sector is identified to have relevant role in the economic performance of ethanol sector, as enzyme production has in second generation ethanol sector. The results present in this article can provide valuable information for decision-making in both biofuels to address new initiative for effective economic and environmental policies efforts.
\end{abstract}

Keywords: Ethanol; Cellulosic ethanol; Structural path analysis; Input-output multipliers; Brazil

\section{Introduction}

The increase in global biofuel production is driven primarily by the energy policies that have been adopted in important energy markets to promote the production and use of biofuels [1-5]. The United States has adopted a Renewable Fuel Standard (RFS2) that mandates an increase in the use of renewable biofuels, an significant portion of which must be derived from lignocellulosic biofuels by 2022 [5,6]. In 2009, The European Union adopted the Renewable Energy Directive (RED), which promote the use of renewable energy sources and established a requirement that $10 \%$ of transport energy be based on renewable energy sources. In 2012 the European Commission (EC) proposed to limit the use of food-based biofuels to meet the $10 \%$ renewable energy target to $5 \%$, stimulating the development of alternatives, such as lignocellulosic biofuels.

Thomassen et al. [7] point out that sustainability is a holistic concept consisting of three domains: economic, environmental, and social, also referred to as the three pillars: profit, planet, and people. The literature mentions that biofuel sustainability is associated to the generation of skilled labor, improvements in living conditions for workers, the socioeconomic development of rural areas in middle- and low-income countries, avoidance of competition between food and energy crops and social conflicts, nature preservation, and the reduction of greenhouse gas emissions $[2,4,8,9]$.

Pires and Schechtman [5] and OECD/IEA [4] depict the environmental life cycle performance of bioethanol from different raw materials. These reports show that sugar cane and lignocellulosicderived ethanol are among the optimal biofuel technological strategies for reducing greenhouse gas emissions [10]. Thomassen et al. [7] define Life Cycle Assessment (LCA) as a tool used to evaluate the environmental impact of a product throughout its life cycle, of which it describes the microstructure of an ecological-economic system.

Bagasse is denoted as the potential feedstock for lignocellulosicderived ethanol production in Brazil. The primary advantage related to the use of sugar cane bagasse is the feasibility of integrating bagasse-derived ethanol plants into the existing sugar cane ethanol infrastructure, reducing infrastructure and logistic costs as well as the implementation and production cost $[4,8,11]$. Kadam [12] executed a Life Cycle Assessment (LCA) to assess the options of converting excess bagasse to ethanol versus discarding it as waste, where was compared the use of E10 fuel blend (containing 10\% bioethanol by volume) with the gasoline for motor vehicle use in Mumbai. LCA studies charactering the potential bagasse-derived ethanol production in Brazil have been not found, as well as LCA studies integrating economic (beyond life cycle costing) and environmental impacts for identifying a path towards the sustainability of Brazilian ethanol sector.

Structural Path Analysis (SPA) is a method that can compute the economic and environmental impacts of any economic sector, from a macro LCA perspective. According to Lenzen and Murray [13], SPA is an input-output technique that is used to trace and scan an entire supply and sales chain web in order to extract and rank those structural paths (input chains) that are most important in terms of the economic and environmental contributions. The database used in a SPA is constructed from national accounts and covers a wider system than a conventional LCA, without suffering of errors caused by truncation due to system delimitations and non-representative data, especially for countries without life cycle database. Limitations of a SPA based on IO database are based on some assumptions: technical coefficient constants, liner production function, and supply perfectly elastic. In

*Corresponding author: Caldeira-Pires Armando, Professor, Department of Mechanical Engineering, Faculty of Technology, University of Brasilia, Brazil, Tel: 556-131-075-710; E-mail: armandcp@unb.br

Received March 01, 2016; Accepted March 25, 2016; Published March 29, 2016

Citation: Palma-Rojas S, Caldeira-Pires A, Nogueira J (2016) Economic and Energy Performance of Brazilian Bagasse-Derived Ethanol: A Macro Perspective. J Bioprocess Biotech 6: 273. doi:10.4172/2155-9821.1000273

Copyright: (c) 2016 Silvia P, et al. This is an open-access article distributed under the terms of the Creative Commons Attribution License, which permits unrestricted use, distribution, and reproduction in any medium, provided the original author and source are credited. 
addition, uncertainties increase in a SPA through use of average values of the set of industries, aggregation of products to sectors, monetary transitions between currencies and time, use of outdated data [14-16].

Acquaye et al. [1] use hybrid LCA to calculate the $\mathrm{CO}_{2}$ emissions of a typical biodiesel supply chain, and SPA to identify, quantify and rank high carbon emissions paths in the supply chain. Thus, by a consistent manner, structural path analysis can assist in tailoring and prioritizing sustainability efforts in an economy $[17,18]$.

This study aims to characterize the economic and environmental performance of bagasse-derived ethanol over their life cycle, from a cradle-to-gate perspective, according to LCA terminology. This characterization is based on a macrostructure of the Brazilian economic system, and identifies, quantifies and ranks all input chains that contribute most to the sustainability of the Brazilian bagassederived ethanol. This SPA uses the Brazilian 2005 Input-Output table as a database to compute the economic and environmental impacts. The economic factors, Gross Domestic Product (GDP) and employment (E), identify the economic contribution of the new sector in the economy. The environmental factors, $\mathrm{CO}_{2}$ emissions $\left(\mathrm{CO}_{2}\right)$ and fuel consumption (TJ), evaluate bagasse ethanol as a technological strategy for reducing greenhouse gas emissions and energy consumption in the Brazilian economy

\section{Methods}

To characterize the economic and environmental performance of bagasse-derived ethanol over their life cycle, a SPA based on the generalized input-output model (IO) has been applied using the national economic accounts provided by the Brazilian Statistics Institute (IBGE) for 2005. According to Lenzen [19], IO is a top-down economic technique that uses sectoral economic transactions to account the interdependency of industries in modern economies. The core of an IO model is the inter industry requirements or technical coefficient matrix $\mathbf{A}=\left|\mathrm{a}_{\mathrm{i}}\right|$, where the columns of $\mathrm{A}$ represent the input technology for producing one unit of each economic sector [20,21]. Classical IO model quantifies the total production of the economic activities related to a final demand composed of household and government consumption and export. Hence, the total production (x) of an economy is,

$$
\mathbf{x}=(\mathbf{A}-\mathbf{I})^{-1} \mathbf{f}=\left(\mathrm{I}+\mathbf{A}+\mathbf{A}^{2}+\ldots\right) \mathbf{f}=\mathbf{L} \mathbf{f}
$$

Where I represent the identity matrix, $\mathrm{f}$ is the final demand vector and $\mathrm{L}$ is the Leontief inverse matrix known also as total requirements matrix. A generalized IO analysis goes beyond the traditional total production analysis, because it quantifies the output of different production factors (Gross Domestic Product-GDP, Labor-E, emissions$\mathrm{CO}_{2}$ and Energy-TJ) associated with final demand, as shown in equation (2).

$$
\mathbf{x}_{\mathbf{b}}=\mathbf{b}(\mathbf{A}-\mathbf{I})^{-1} \mathbf{f}=\mathbf{b}\left(\mathbf{I}+\mathbf{A}+\mathbf{A}^{2}+\mathbf{A}^{3}+\mathbf{A}^{4}+\mathbf{A}^{5}+\mathbf{A}^{6}+\mathbf{A}^{7}+\mathbf{A}^{8}+\ldots+\mathbf{A}^{\mathrm{n}}\right) \mathbf{f}=\mathbf{b L f}
$$

Where $\mathbf{b}$ is the matrix of production factor coefficients in specific unit per monetary unit.

In a further analysis of the global effect that is observed in a generalized IO analysis, the SPA unveils the Leontief inverse matrix $(\mathbf{L})$ by considering the multitude of interactions among sectors by means of the respective technical coefficients, $A=\left[a_{i j}\right][16,17,22-24]$, and the use of the concept of path multiplier. This analysis contributes to our understanding of the mechanisms that induce changes in the analyzed sector and assists in identifying the level of integration of an economy [14]. Equation (1) and Equation (2) capture both direct and indirect influences of an economy and can be written as a Taylor expansion $[20,25]$,

$$
\left.\left(b_{i}+\sum_{j=1}^{n+1} b_{j} a_{j, i}+\sum_{k=1}^{n+1} \sum_{j=1}^{n+1} b_{j} a_{j, k} a_{k, i}+\sum_{1=1}^{n+1} \sum_{k=1}^{n+1} \sum_{j=1}^{n+1} b_{j} a_{j, k} a_{k, j} a_{l, i}+\sum_{j=1}^{n+1} \sum_{k=1}^{n+1} \sum_{k=1}^{n+1} \sum_{j=1}^{n+1} b_{j} a_{j, k} a_{k, k} a_{b, j} a_{i, i}+\ldots\right) f_{i}\right)
$$

Where $\mathrm{i}, \mathrm{k}, \mathrm{l}$, and $\mathrm{j}$ denote sectors. The second sum element of the right side represents a structural path that quantifies the contribution of the sector $\mathrm{j}$ when producing for fulfilling the demand of sector $\mathrm{k}$ associated with the final demand of sector $i$. Thus, $x_{b, i}$ is a sum over a direct influence of sector $\mathrm{i}\left(\mathrm{b}_{\mathrm{i}}\right)$ and higher-order structural paths multiplied by the final demand of the analyzed sector i. According to Acquaye et al. [1], each element in (3) represents the contribution of an individual input path. Lenzen and Murray [13] point out that within SPA, the term "path" is used as a synonym for "chain", and similarly, intermediate transactions in a chain are referred to as "nodes". Finally, the number of intermediate actors (sectors j,k,l) in a chain is called the "order" of that path.

Thus, an input path consists of one or more consecutive nodes that are connected to the origin sector $i$, in which the exogenous shock occurs, to destination sector $\mathrm{j}$, in which the change is provoked $[17,18,26]$. There are input paths of zero order, first order, second-order and up to the $\mathrm{n}^{\text {th }}$ order. For example, in an economy with $\mathrm{n}$ sectors, there are $\mathrm{n}^{\mathrm{n}}$-structural paths of the $\mathrm{n}^{\text {th }}$-order $[13,27]$. However, the result of summing those paths is a finite number because the value of an input path decreases with path length $[13,18,19,22,23,27]$.

\section{Database preparation}

The alignment of monetary and physical data was necessary for two reasons: integrated environmental-economic accounts are not published by IBGE, and sectoral classification in the IO table differs from the sectoral classification that is used in physical data reports, the National Energetic Balance Report [28] and the Carbon Balance Report [29]. The Brazilian Use and Make tables, which serve as basis to construct IO database, are structured into 110 products and 55 sectors that were aggregated into 18 sectors to enable the physical and economic data integration. The most updated IO and physical data officially published is for 2005 .

The main reason to use the IO and physical data is to obtain the technical coefficient matrix (A) and the production factor coefficient matrix (b) with the same base year. According to Miller and Blair [20], measures such as total economy-wide output associated with a specific vector of final demand, the error introduced by an outdated table may be not be large. Additionally, Miller and Blair [20] mention that some studies found that extrapolations from updating and projecting coefficient methods generated worse results than simply using the most recent coefficient table available. Thus, we presume that the technical coefficients used in this study reflect the actual economic dynamic.

To study the hypothetical SGe sector was necessary to incorporate it into the original IO database. According to Miller and Blair [20], IO approach provides a framework within which to assess the impacts associated with the introduction of a new sector into an economy. IO literature discusses mainly two ways of introducing a new economic activity, through a new final-demand vector and through the addition of new elements into the technical coefficients matrix. For Chowdhury and Krikpatrick [30] the problem of introducing new activities is handled by adding new rows and columns with technical coefficients obtained either from engineering data or on the basis of statistical experience of similar activities already established in regions or in countries of comparable economic development [20].

The scenario of the hypothetical SG ethanol sector was based on 
data from Walter and Ensinas [31], Dias et al. [11] and Ferreira-Leitão at al. [32] for technological structure of the potential plant, and from Fu et al. [33], Gonzales-García [34], Kadam [12]; Mac Lean and Sparati [35]; Spatari et al. [36] for "input technology". The final demand projection was set according to annual sugar cane time series data from Brazilian Sugar cane Industry Association (UNICA) and forecast demand scenarios from Filho and Macedo [37]. According to Miller and Blair [20], when the level of new sector activity is specified in terms of sales to final demand rather than total production $(\mathrm{x})$, no new principles are involved in assessing the impacts.

To estimate the new coefficients, in first place were introduced the economic data into the Supply and Use Tables (SUTs) from national accounts $[20,38]$. Original SUTs were aggregated into five foreground sectors, FG Ethanol sector-FGe (Bagasse production), Chemical sector (lime, sulfur acid and DAP production), other chemical sector (enzymes production), and ISPU and hypothetical SGe sectors (bioelectricity sold), and into one background sector aggregating the rest of the economy. Thus, we used the aggregated SUTs for obtaining the new $\mathbf{A}_{\text {new }}=\mathbf{D B}$ and $\mathbf{f}_{\text {new }}=\mathbf{D e}$, where $\mathbf{D}$ is the market share matrix, $\mathbf{B}$ is the parallel of technical coefficient matrix from Use table, and $\mathbf{e}$ is the final demand for commodities [20]. We incorporate those coefficients of foreground sectors into the new column of $\mathbf{A}_{[19 \times 19]}$ that is completed by background coefficients associated to FGe input technology. These coefficients were assumed to be the same because future landscape of ethanol industry projects the feasibility of integrating bagasse-derived ethanol plants into the existing ethanol infrastructure; thus, both sectors potentially will share the same input technology from those background sectors. Similarly, it is assumed that direct coefficients associated to economic factors follow the same structure of FGe sector. And, those related to environmental factors are considered zero because in our hypothetical model non-direct energy consumption or externalgrid electricity is used in the hypothetical SGe sector; sources of $\mathrm{CO}_{2}$ emissions and energy consumption in this study.

\section{Results and Discussion}

This study identified, quantified and ranked the input paths with the greatest contributions to the economic, environmental and energy performance of bagasse-derived ethanol on the basis of four factors: Gross Domestic Product (GDP), employment (E), $\mathrm{CO}_{2}$ emissions $\left(\mathrm{CO}_{2}\right)$ and fuel consumption (TJ). Figures 1 and 2 depict the 10 highest ranked structural paths for economic, and environmental and energy factors, respectively.

The hypothetical structure for GDP in the SGe sector has a direct influence of $46.5 \%$, and the remaining $53.5 \%$ is distributed among more than 3000 input paths of different orders. In the assumed technology modeling, the important economic relation among the foreground sectors responsible for enzyme production ( $\mathrm{SGe} \rightarrow \mathrm{OChe}$ ) and chemical production ( $\mathrm{SGe} \rightarrow \mathrm{Che}$ ) is evident, ranking in second and third position in terms of total GDP influence, respectively. According to MacLean and Spatari [35], ethanol production through biochemical processes utilizes chemicals for pretreatment, hydrolysis, and fermentation. Chemicals required vary depending on the specific processes employed. Enzymes assist with liquefaction, saccharification, and fermentation and are also associated with other process benefits in ethanol production. Nowadays, the enzymes used in converting lignocellulose to ethanol are still in development and the prices of those in commercial stage are not as inexpensive as those used for corn-derived ethanol production.

The sum of three first-order input paths and the direct GDP represents approximately $59 \%$ of the total GDP impact. In addition to the GDP generated from the commerce-services sector, by means of SGe (SGe $\rightarrow \mathrm{Co}$ ), the chemical sector ( $\mathrm{SGe} \rightarrow \mathrm{Che} \rightarrow \mathrm{Co}$ ), and the enzyme sector ( $\mathrm{SGe} \rightarrow \mathrm{Oche} \rightarrow \mathrm{Co}$ ), FG ethanol has also an important intervention in GDP because its sugar cane bagasse production, raw material for SGe production.

The employment generation has a direct influence estimated at $25 \%$. The indirect job creation comprises several important input paths, such as $\mathrm{SGe} \rightarrow \mathrm{Co}$, SGe $\rightarrow \mathrm{Oche}, \mathrm{SGe} \rightarrow \mathrm{Che} \rightarrow \mathrm{Co}, \mathrm{SGe} \rightarrow \mathrm{Fb} \rightarrow \mathrm{Alf}$, $\mathrm{SGe} \rightarrow \mathrm{Oche} \rightarrow \mathrm{Co}$. We identified that the aggregated share of commerceand-services sector is a relevant contributor in job creation along with the sectors of enzymes and agricultural production. In the current agro ethanol industry (agricultural and industrial activities), the agricultural phase (sugar cane production) is the main employment generator, typically characterized by low-skilled activities. On the other hand, the industrial phase is characterized by higher-skilled activities. In the hypothetical SGe sector modeled here with the same employment structure of the sugar cane ethanol sector, the industrial stage ranks first and agricultural stage and bagasse production are not part of the topten structural paths. Thus, SGe industry has the potential of generating indirectly more skilled jobs than sugar cane ethanol.

For both job and GDP generation, the chemical sector, the enzyme

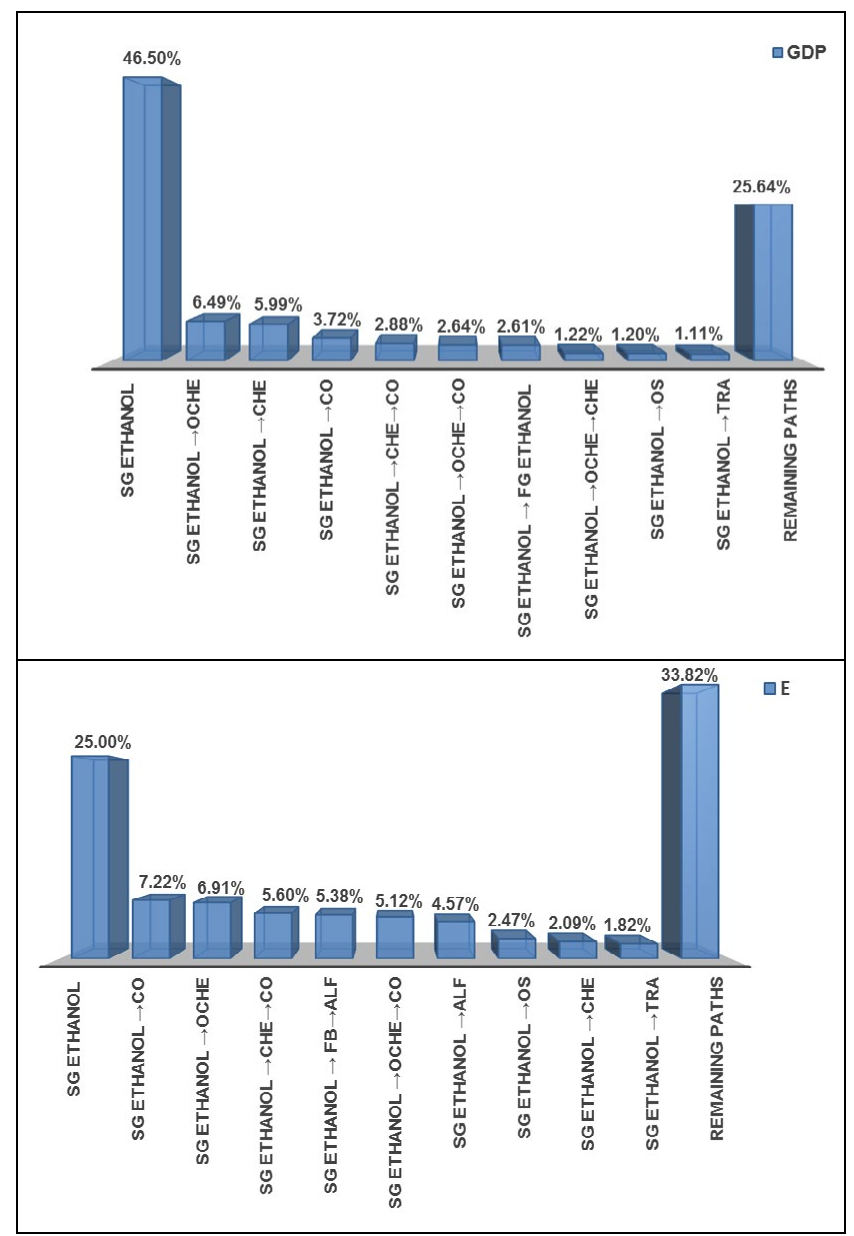

Figure 1: Top-ranking Structural Paths in Terms of GDP and Employment (\%) Sectors: SG; Ethanol: SGE Bagasse Ethanol; FG ethanol: FGe Sugar Cane Ethanol; OCHE: Others Chemicals; CHE: Chemical; CO: Commerce-andServices; FB: Food-Beverage; OS: Other Industrial Sectors; EN: Energy; TRA: Transport; ALF: Agricultural-Livestock-Fishing; SC: Sugar Cane. 
sector and the commerce-and-service sector play an important role in the economic performance of the hypothetical SGe production, when it is assumed a domestic production for all its inputs. According to OECD/IEA [4], international enzyme manufacturers have undertaken research projects in cooperation with Brazilian national research institutions and many of them plan to install and expand research capacity in advanced biofuels in Brazil (Figure 1).

The $\mathrm{CO}_{2}$ emission impact for the SGe sector has only indirect influences because our modeling assumes non-fossil energy sources in SGe plants. Our cradle-to-gate results show that the input paths that most influence the $\mathrm{CO}_{2}$ emission performance are: $\mathrm{SGe} \rightarrow \mathrm{Tra}$, SGe $\rightarrow \mathrm{Che} \rightarrow \mathrm{Tra}$, $\mathrm{SGe} \rightarrow \mathrm{Che}, \mathrm{SGe} \rightarrow \mathrm{Oche} \rightarrow \mathrm{Tra}, \mathrm{SGe} \rightarrow \mathrm{Met}, \mathrm{SGe} \rightarrow \mathrm{FGe} \rightarrow \mathrm{Sc}$ and $\mathrm{SGe} \rightarrow$ Oche. This result illustrates the relevant influence of transportation services in the environmental performance of SGe due, mainly, to the high amount of diesel oil burned in the transport process. Also, as confirmed by MacLean and Sparati [35], the feedstock, chemical and enzymes production, are on the top list of $\mathrm{CO}_{2}$ emitters for SGe. Additionally, our analysis identified that the metallurgic products used in installation or maintenance services in the SGe plant and the sugar cane production can potentially influence also the total $\mathrm{CO}_{2}$ emissions.

For the same reasons of $\mathrm{CO}_{2}$ emission impact, the energy consumption has only indirect influences. This cradle-to-gate result shows that the relevant influence in fuel consumption is composed of different input paths led by transport, chemical and metallurgy sectors, and sugar cane production. Singh et al [39], MacLean and Sparati [35] and $\mathrm{Fu}$ et al. [33] also found that chemical/enzyme production and transport are important sources of energy consumption in $\mathrm{SGe}$ production. The enzyme production is ranked here at $19^{\text {th }}$ position (Figure 2).

Despite the limitation related to the SPA model and the IO database, the results in this analysis confirm the outcomes found in the technical literature, where the chemical, enzyme, and commerceand-services sectors are relevant for the economic performance of the bagasse-derived ethanol. It is important to mention that the commerceand-service sector is the main contributor in employment and Gross Domestic Product generation in the Brazilian economy. That reality was reproduced in the economic results of this analysis.

Likewise, the environmental and energy results are attributed, mainly, to the intensive use of fossil fuels in the chemical, transportation and sugar cane sectors in Brazil. Those sectors supply the main energy resource and inputs for bagasse ethanol production. Additionally, this analysis corroborates the literature perspective, where it is pointed out second generation biofuel as a potential alternative for establishing a sustainable biofuel industry, expecting an improvement in the economic situation of rural areas in developing countries, creation of more skilled jobs, and reduction of GHG emissions and fossil-derived fuels consumption $[4,5,40]$.

\section{Conclusion}

Brazil is confronting the challenge of attaining sustainability in the ethanol sector while maintaining its position as a leader in biofuel initiatives and important supplier of ethanol to the world market in this new era of sustainable biofuel policies and international commitments where renewable energy and transport sector play an important role in the current climate change framework.

This cradle-to-gate analysis assisted in identifying input paths, in which efforts can be exerted to effectively promote sustainability in the sector. We observed that the economic performance of the bagasse-

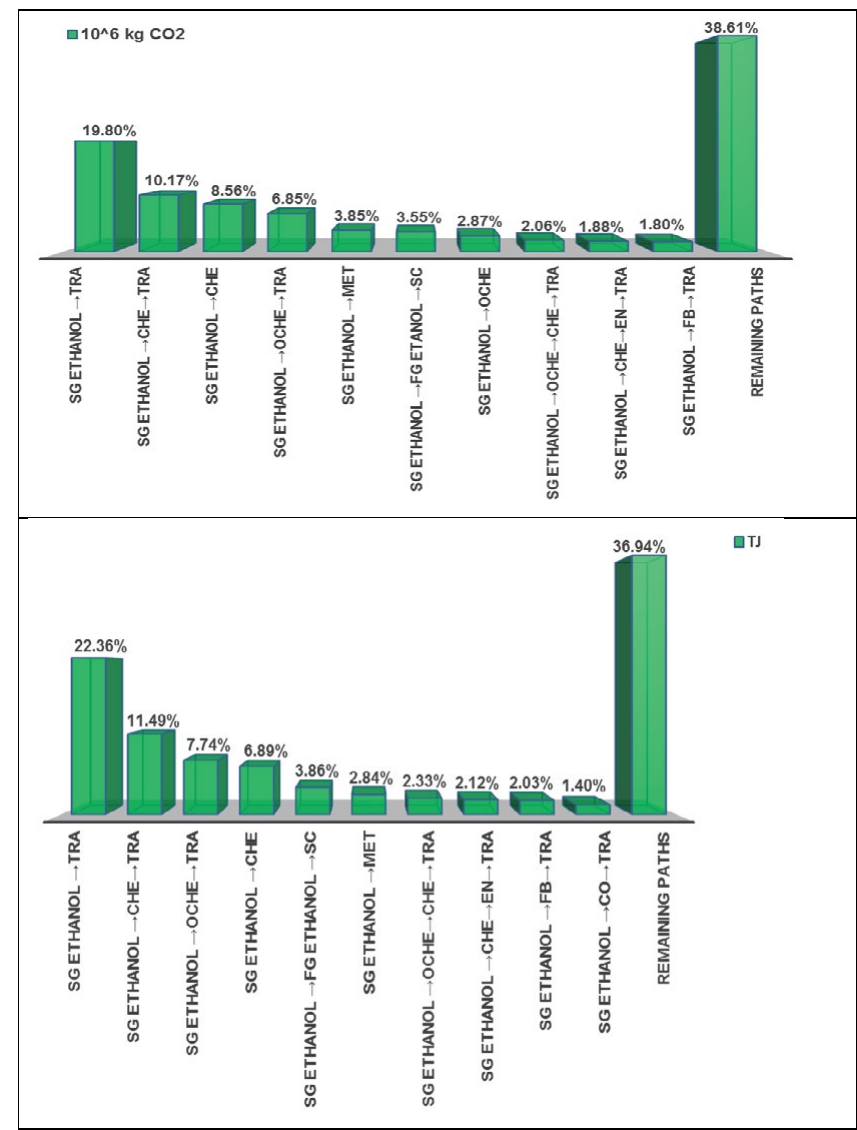

Figure 2: Top-ranking Structural Paths, in Terms of $\mathrm{CO}_{2}$ Emissions and Energy Consumption (\%). Sectors: SG; Ethanol: SGE Bagasse Ethanol; FG ETHANOL: FGE Sugar Cane Ethanol; OCHE: Others Chemicals; CHE: Chemical; CO: Commerce-and-Services; FB: Food-Beverage; EN: Energy; TRA: Transport; SC: Sugar Cane; MET: Metallurgy.

derived ethanol industry depends on direct actions in its industrial phase and in the production structure of chemicals, enzymes and commerce-and-services suppliers. Thus, a legal framework favorable to those sectors could influence positively the economic dynamics. The environmental panorama of this potential sector calls also for introducing cleaner energy sources in transport services and chemical processes. Hence, political support towards technological innovation, and research and development on advanced biofuels will keep Brazilian ethanol industry competitive internationally, at the same time that brings economic and environmental benefits for the country.

\section{References}

1. Acquaye AA, Wiedmann T, Feng K, Crawford RH, Barrett J, et al. (2011) Identification of 'carbon hot-spots' and quantification of GHG intensities in the biodiesel supply chain using hybrid LCA and structural path analysis. Environ Sci Technol 45: 2471-2478.

2. Ajanovic A, Haas R (2010) Economic challenges for the future relevance of biofuels in transport in EU countries. Energy 35: 3340-3348.

3. Carriquiry MA, Du X, Timilsina G (2011) Second Generation Biofuels: Economics and Policies. Energy Policy 39: 4222-4234.

4. International Energy Agency (2010) Sustainable production of second generation biofuels: Potentials and perspectives in major economies and developing countries. International Energy Agency, France.

5. Pires A, Schechtman R (2010) O Mapa sucroenergetico do Brasil, De Souza and Macedo (Eds), Etanol e Bioeletricidade: A Cana-de-Açúcar no futuro da matriz energetica, UNICA, Brazil. 
Citation: Palma-Rojas S, Caldeira-Pires A, Nogueira J (2016) Economic and Energy Performance of Brazilian Bagasse-Derived Ethanol: A Macro Perspective. J Bioprocess Biotech 6: 273. doi:10.4172/2155-9821.1000273

Page 5 of 5

6. http://www.epa.gov/otaq/fuels/renewablefuels/regulations.htm

7. Thomassen MA, Dolman MA, van Calker KJ, de Boer IJM (2009) Relating life cycle assessment indicators to gross value added for Dutch dairy farms. Ecological Economics 68: 2278-2284.

8. International Energy Agency (2008) From $1^{\text {st }}$ to $2^{\text {nd }}$ Generation Biofue Technologies: An overview of current industry and RD\&D activities. International Energy Agency, France.

9. Walter A, Verde Leal MR (2010) Sustentabilidade da Produtividade e do Consumo de Biocombustíveis. In: Bioetanol de Cana-de-Açúcar: P\&D para Produtividade e Sustentabilidade. Cortez LA (Eds). FAPESP, Brazil.

10. Bai Y, Luo L, Der Voet E (2010) Life cycle assessment of switchgrass-derived ethanol as transport fuel. Int J Life Cycle Assess 15: 468-477.

11. Dias MO, Cunha MP, Jesus CD, Rocha GJ, Pradella JG, et al. (2011) Second generation ethanol in Brazil: can it compete with electricity production? Bioresour Technol 102: 8964-8971.

12. Kadam KL (2002) Environmental benefits on a life cycle basis of using bagassederived ethanol as a gasoline oxygenate in India. Energy Policy 30: 371-384.

13. Lenzen M, Murray J (2010) Conceptualising environmental responsibility Ecological Economics 70: 261-270.

14. Ardent F, Beccali M, Cellura M (2009) Application of the IO Methodology to the Energy and Environmental Analysis of a Regional Context. Handbook of InputOutput Economics in Industrial Ecology 23: 435-457.

15. Lenzen M (2000) Errors in Conventional and Input-Output-based Life-Cycle Inventories. J Ind Ecol 4: 127-148.

16. Suh S (2004) Functions, commodities and environmental impacts in an ecological-economic model. Ecological Economics 48: 451-467.

17. Defourny J (1982) Une approche structurale pour l'analyse input-output : un premier bilan. Economie Appliquée 35: 203-230.

18. Defourny J, Thorbecke E (1984) Structural Path Analysis and Multiplier Decomposition within a Social accounting Matrix Framework. The Economic Journal 94: 111-136.

19. Lenzen M (2002) A guide for compiling inventories in hybrid life-cycle assessments: some Australian results. J Clean Prod 10: 545-572.

20. Miller RE, Blair PD (2009) Input-output Analysis: Foundations and Extensions. Second edition. Cambridge University Press, Cambridge, UK.

21. Peters G, Hertwich E (2006) Pollution embodied in trade: The Norwegian case. Global Environmental Change 16: 379-387.

22. Lenzen M (2003) Environmentally important paths, linkages and key sectors in the Australian economy. Structural Change and Economy Dynamics 14: 1-34.

23. Lenzen M (2007) Structural path analysis of ecosystem networks. Ecol Modell 200: 334-342.
24. Wood R, Lenzen M (2009) Structural Path Decomposition. Energy Economics 21: 335-341.

25. Waugh FV (1950) Inversion of the Leontief Matrix by Power Series. Econometrica 18: 142-154

26. Roberts $D$ (2005) The role of households in sustaining rural economies: a structural path analysis. European Review of Agricultural Economics 32: 393-420.

27. Baboulet O, Lenzen M (2010) Evaluating the environmental performance of a university. J Clean Prod 18: 1134-1141.

28. MME (2010) Brazilian Energy Balance 2010: year 2009. Empresa de Pesquisa Energética (EPE), Rio de Janeiro.

29. MCT (2007) Balanço de Carbono nas atividades energéticas do Brasil Economia e Energia-e\&e-OSCIP No 13.0020.00/2005.

30. Chowdhury A, Kirkpatrick C (1994) Development Policy and Planning: An introduction to models and techniques. Routledge Taylor \& Francis Group, New York, USA.

31. Walter A, Ensinas A (2010) Combined production of second-generation biofuels and electricity from sugarcane residues. Energy 35: 874-879.

32. Ferreira-Leitão V, Gottschalk LMF, Ferrera MA, Nepomuceno AL, Milinari HBC (2010) Biomass Residues in Brazil: Availability and Potential Uses. Waste Biomass Valor 1: 65-76.

33. Fu GZ, Chan AW, Minns DE (2003) Life Cycle assessment of bio-ethano derived from cellulose. Int J Life Cycle Assess 8: 137-141.

34. Gonzales-García S, Luo L, Moreira MT, Feijoo G, Huppes G (2009) Life cycle assessment of flax shives derived second generation ethanol fueled automobiles in Spain. Renewable and Sustainable Energy Review 13: 1922-1933.

35. Mac Lean H, Sparati S (2009) The contribution of enzymes and process chemicals to the life cycle of ethanol. Environ Res Lett 4: 014001.

36. Spatari S, Zhang Y, MacLean HL (2005) Life cycle assessment of switchgrassand corn stover-derived ethanol-fueled automobiles. Environ Sci Technol 39 9750-9758.

37. Filho L, Macedo I (2010) O mapa sucroenergético do Brasil. In: Etanol Bioeletricidade: A Cana-de-Açúcar no futuro da matriz energética. De Souza and Macedo (Eds). UNICA, Brasil.

38. Paixão PTG (2010) Electric cars in Brazil: A method for assessing innovation impacts on the economy. World Energy Council-Congress paper.

39. Singh A, Pant D, Korres NE, Nizami AS, Prasad S, et al. (2010) Key issues in life cycle assessment of ethanol production from lignocellulosic biomass: Challenges and perspectives. Bioresour Technol 101: 5003-5012.

40. Arndt C, Garcia A, Tarp F, Thurlow J (2011) Poverty Reduction and Economic Structure: Comparative Path Analysis for Mozambique and Vietnam. Review of Income and Wealth 58: 742-763. 